\title{
仮想ストレス状況下におけるインプリシットとエクスプリシット感情の変動が 情動焦点型コーピングに与える影響の予備的研究
}

\author{
○内田 香奈子 \\ (鳴門教育大学) \\ キーワード : コーピング，感情
}

Effects of implicit and explicit affect on emotion-focused coping in hypothetical stressful situations: A preliminary study

Kanako Uchida

(Naruto University of Education)

Key Words : stress coping, affect

\section{目的}

情動焦点型コーピング(emotion-focused coping)

は, Fol kman \& Lazarus (1980)に代表されるコーピングの下 位概念であり，ストレスフルな感情を調整しょうとする対処 を指す。他方は問題焦点型コーピング( probl em-focused coping）で，ストレスの原因への対処を指す。この2つのコー ピングが健康や適応に与える影響を概観すると, 問題焦点型 コーピングは適応の向上に寄与する知見 (e.g., Riley \& Park, 2014) が示されている。一方の情動焦点型コーピング は，知見が混乱している(内田，2018）。

混乱の原因は何であろうか?この疑問へアプローチするた めのひとつとして, 本研究では情動焦点型コーピングがター ゲットとする感情の動きに着目する。近年, 感情の機能につ いては，意識下にある感情の機能が强調され，その一部はイ ンプリシット感情( impl icit affect；IA)として測定され始め ている(Quirin et al., 2009)。そして, エクスプリシット感 情(explicit affect; EA)のみでは明らかにされなかった知見 や，両感情の相互作用が健康・適応に及ぼす影響が明らかに されつつある(e.g., Quirin \& Lane, 2012)。この研究文脈よ り, 問題ある感情に働きかける情動焦点型コーピングも，そ の適用前のEAとIAの高さをとらえる必要があることがわか る。なお, 感情は状態と特性の両様相が存在するため, ス卜 レス状況下において大きく変動する可能性を持つ。本研究で は，測定状況をより統一するため仮想的なストレス状況下を 設定する。その上で, IAとEAが情動焦点型コーピングに与え る影響を検討する。

\section{方 法}

調査対象者 大学院生 40 名。このうち, 2 回とも研究への同意 が得られた者, ならびに欠損データを除く 22 名 (男性7名, 平 均年齢30.14歳, $\mathrm{SD}=10.75$, 女性 15 名, 平均年齢 26.93 歳, $\mathrm{SD}=8.32)$ を分析対象とした。

查定道具

1) Emotional Approach Coping Scale(EAC) 日本語 - 状況版 （内田, 2018)Stanton et al.(2000)によって原版が開発さ れた。最近感じたストレスへの情動焦点型コーピングを測定 する尺度であり, 感情処理と感情表出の 2 下位尺度から構成 される。4件法で回答を求めた。

2) Impl icit Positive and Negative Affect Test(IPANAT) 日本語版（下田他，2014）Quirine et al.(2009)によって原版 が開発された。インプリシット正負感情( impl icit positive affect：IPA, impl icit negative affect：INA)を測定する尺 度。4件法で回答を求めた。

3) Positive and Negative Affect Schedule(PANAS) 日本語 版(佐藤・安田, 2001) Watson et al.(1988)によって原版が 開発された。エクスプリシット正負感情( expl icit positive affect: EPA, explicit negative affect：ENA)を測定する尺 度。現在の気分の程度について，6件法で回答を求めた。
手続き 大学院の講義を利用して2回実施した。実施は, 実施 者が協力者へ直接教示した。協力者には調査への協力は強制 ではない旨を伝え，参加に同意を得た。1回目 (timel：T 1) は 協力者のベースラインの測定を目的とし，3尺度に回答を求め た。2回目 ( t ime2：T2) の調査は約1 ケ月後に実施した。まず, 仮想ストレス状況を設定するため, 講義のはじめに小テスト を5分程度実施した。小テストは講義内容の復習も兼ねるた め, 全員参加とした。次に, 続けて1回目と同様に 3 尺度へ回 答を求めた。調査後には事後説明を行った。なお, 小テスト は全員参加としたが，最終的に回収はせずに解説のみ行い， その得点も成績には関係のない旨を伝えた。本研究は, 鳴門 教育大学研究倫理審査委員会の承認とJSPS科研費 JP16K17335 の助成を受けて実施した。

\section{結 果 と 考 察}

$\mathrm{T} 1$ と比較し, $\mathrm{T} 2$ の各変数に変動が見られたのかを確認する ため, 各変数について時期 $\times$ 性の 2 要因分散分析を行った。そ の結果, EPAでは時期の主効果 $(F(1,20)=9.15, p<.01)$ と交互作用 $(\mathrm{F}(1,20)=16.60, \mathrm{p}<.01)$ に有意な值が確認 された。それ以外の変数(各コーピングやIA， ENA)では有意な 值は確認されなかった。

次に T1の各感情がT2のコーピングヘどのような影響を与え るのかを確認するため, T1のIPA・INAあるいはEPA・ENAを独 立変数, T2の各コーピング変数を従属変数として重回帰分析 を行った。その結果, 有意傾向ではあったが, T1におけるINA の高さがT2の状沉的な情動焦点型コーピング(感情表出)を低 める結果を確認した。なお, 感情の変動に着目し, T2からT1 の各感情の差が, T2でのコーピングに与える影響も同様に確 認したが，有意な回帰係数は確認されなかった。ただし，こ の研究では各変数においてT1 とT2 との間に有意な差がほとん ど確認されなかったことから, その介入操作が上手くできて いない可能性があった。また, 今回は介入群のみの検証で あったが, 本来であれば統制群も設定した上での検証を行う 必要がある。

Table 1 Results of emotion-focused coping as explanatory variables

\begin{tabular}{|c|c|c|c|}
\hline Dependent variables & Explanatory variables & $\beta$ & $R^{2}$ \\
\hline \multirow[t]{2}{*}{ T2 Emotional Processing } & T1 Implicit Positive Affect & .26 & \multirow[t]{2}{*}{-.05} \\
\hline & T1 Implicit Negative Affect & -.05 & \\
\hline \multirow[t]{2}{*}{ T2 Emotional Expression } & T1 Implicit Positive Affect & .45 & \multirow[t]{2}{*}{-.18} \\
\hline & T1 Implicit Negative Affect & $-.50 \dagger$ & \\
\hline \multirow[t]{2}{*}{ T2 Emotional Processing } & T1 Explicit Positive Affect & .34 & \multirow[t]{2}{*}{.15} \\
\hline & T1 Explicit Negative Affect & .17 & \\
\hline \multirow[t]{2}{*}{ T2 Emotional Expression } & T1 Explicit Positive Affect & .12 & \multirow[t]{2}{*}{.02} \\
\hline & T1 Explicit Negative Affect & .06 & \\
\hline
\end{tabular}

Note. $\mathrm{T} 1=$ Time $1, \mathrm{~T} 2=$ Time $2, \uparrow p<.10$ 